\title{
PENJADWALAN DISTRIBUSI DENGAN METODE DISTRIBUTION REQUIREMENT PLANNING (DRP) DI PT. BINA USAHA BERSAMA SEHATI LHOKSEUMAWE
}

\author{
Sri Meutia, Khairul Anshar \\ Jurusan Teknik Industri, Fakultas Teknik, Universitas Malikussaleh, Lhokseumawe, Aceh Utara-NAD \\ Jl. Kampus Unimal Bukit Indah, Blang Pulo, Muara Satu Aceh Utara \\ e-mail: srimeutia_mti@yahoo.co.id
}

\begin{abstract}
Abstrak- PT. Bina Usaha Bersama Sehati merupakan perusahaan yang bergerak dibidang distributor ice cream walls. Produknya terdiri dari beragam macam rasa dan varian. Dalam hal ini Perusahaan telah mendapat kepercayaan untuk mendistribusikan produknya langsung ke outlet yang ada di kota Lhokseumawe dan kota bireuen. Distribusi yang dilakukan perusahaan didasarkan atas penjualan distributor sebagai warehouse sebanyak rata-rata 9300 box (perbulan), sedangkan perusahaan menerima 11.000 box dari medan. Hal tersebut terlihat bahwa penjualan untuk semua jenis produk kurang terkontrol. Perusahaan belum memiliki suatu perencanaan yang terjadwal pada aktivitas distribusi produk, sehingga mengakibatkan terjadinya penumpukan persediaan produk yang terdapat di gudang perusahaan. data penjualan dilakukan dengan hasil perhitungan peramalan permintaan produk oleh perusahaan untuk kota Lhokseumawe 79005 box dan bireun 83659 box, dilanjutkan dengan perhitungan distribusi produk dengan menggunakan metode Distribution Requirement Planning( DRP). Perencanaan penjadwalan distribusi produk ice wall's dengan kapasitas penjualan merupakan hasil penelitian yang dilakukan, dimana dengan metode DRP diperoleh total biaya sebesar Rp. 6.064.193 terlihat adanya penurunan sebesar $5 \%$ dari perhitungan yang dilakukan perusahaan sebelumnya sebesar Rp. 12.060.000,-. Perencanaan penjadwalan distribusi disesuaikan berdasarkan hasil dari penjualan quantity, reorder point dan safety stcok dan setiap distribution centre yaitu distribution centre Lhokseumawe dan distribution centre Bireuen.
\end{abstract}

Kata Kunci - Penjualan, Distribusi produk, Kapasitas, Distribution Requirement Planning( DRP)

\section{PENDAHULUAN}

$\mathrm{D}$ istribution Requirement Planning merupakan suatu metode perhitungan dalam menentukan berapa jumlah titik minimum yang sesuai untuk pelaksanaan suatu persediaan bahan baku digudang. Dalam metode ini menggunakan beberapa perhitungan yang saling terkait berkaitan dengan adanya peramalan permintaan produk. Variabel yang dihitung disesuaikan dengan kebutuhan perusahaan akan perencanaan yang dilakukan nantinya, baik itu penjualan, distribusi, pengadaan bahan baku dan juga jumlah persediaan yang ada di gudang. Distribution Requiremeni Planning lebih ditujukan pada aktivitas pengendalian bahan baku yang masuk dibandingkan dengan pemesanan produk. DRP juga mengantisipasi naik turunnya jumlah permintaan mendatang dengan perencanaan yang telah disesuaikan pada setiap level dan jaringan distribusi produk. Dengan informasi yang tersedia metode ini dapat memprediksi suatu persoalan sebelum masalah-masalah tersebut memberikan dampak terhadap titik pandang pada suatu jaringan distribusi [1][2].

Dalam hal ini perusahaan yang melakukan kegiatan distribusi harus mampu melakukan mendristribusian produk dengan baik dan benar, hal ini dikarenakan salah satu proses yang mendukung keberhasilan perusahaan adalah dengan adanya pendistribusian barang sesuai dengan alur distribusi. Sehingga, untuk meningkatkan produktifitas dan kinerja perusahaan dibutuhkan distribusi produk akhir yang efektif dan efisien terhadap kebutuhan konsumen. Pengertian distribusi merupakan pengendalian, perencanaan, pelaksanaan penyebaran barang yang merupakan salah satu bagian dari aliran material dari produsen secara tepat waktu ke konsumen guna mencapai keuntungan. Jenis distribusi persediaan ada beberapa macam diantaranya sistem dorong dan sistem tarik serta Distribution Requirement Planning (DRP) yang merupakan distribusi fisik dari sistem distribusi [3][4].

Beberapa penelitian terdahulu pernah dilakukan yaitu mengenai perencanaan dan penjadwalan aktivitas distribusi yang diharapkan disetiap prusahaan yang merupakan pengaturan manajemen dalam mengaturan sistem serta aliran distribusi agar sesuai dengan kebutuhan. Capaian sistem distribusi yang baik dapat diketahui dari adanya ketersediaan produk pada pusat-pusat distribusi. Salah satu yang membuat sistem distribusi di perusahaan menjadi baik adalah adanya sistem pencatatan yang terkomputerisasi dan memiliki backup data yang tersimpan rapi dan terintegrasi dalam setiap aktivitas distribusi yang terjadi diperusahaan. Penjadwalan aktifitas distribusi harus mampu menutupi tingkat penurunan kinerja terutama dengan adanya biaya transportasi yang tidak terkendali. Penelitian ini menemukan bahwa adanya biaya transportasi yang sangat besar yaitu sebesar 5,6 milyar rupiah per tahunnya. Metode yang digunakan adalah metode Distribution Requirement Planning (DRP) yang merupakan salah satu metode untuk merancang perbaikan sistem distribusi produk. Langkah awal yang dilakukan dengan melakukan peramalan permintaan 1 tahun yang akan datang. Permintaan tersebut dialokasikan ke dalam pencatatan terstruktur menggunakan software Cargowiz sehingga diperoleh hasil jadwal dalam penentuan perencanaan distribusi yang efektif dan optimal. Dari hasil perancangan yang dilakukan, diperoleh menerapkan DRP pada sistem distribusi perusahaan dan mampu menghemat biaya transportasi sebesar 7,87\%. Hasil yang diperoleh mampu untuk mengurangi pengeluaran biaya distribusi dan mampu 
memperbaiki sistem distribusi yang ada diperusahaan sekarang [4][5].

Selain itu penelitian mengenai perencanaan penjadwalan distribusi produk juga ditemukan adanya masalah yang berhubungan dengan sistem perencanaan distribusi produk pada suatu perusahaan. Adanya masalah dikarenakan adanya konsumen yang lokasi penyebaran tempat tinggal jauh dari perusahaan sehingga untuk mendistribusikan dan untuk memenuhi permintaan pusat-pusat distribusi sering tidak terpenuhi. Masalah tersebut juga dapat diselesaikan dengan metode DRP yaitu untuk mencapai pendistribusian produk dari pabrik ke kota kota distribusi secara efektif, efisien dan juga optimal. Distribution Requirement Planning merupakan suatu metode untuk menyusun menjadwalkan, merancang, memenuhi pengadaan persediaan dalam jaringan distribusi multi eselon. Tujuannya adalah melakukan penjadwalan, pengendalian dan perencanaan aktivitas distribusi yang baik, sehingga keberhasilan dalam pemenuhan kebutuhan dan permintaan konsumen akan menjadi lebih baik, Hasil penjualan dapat meningkat dalam memenuhi permintaan sesuai dengan waktu yang ditentukan dengan jumlah yang sesuai sehingga biaya distribusi dapat menjadi optimal. Hasil Penelitian menunjukkan sistem penjadwalan, pengendalian dan perencanaan sistem distribusi mampu menekan total biaya sesuai dengan biaya penyimpanan, biaya pengiriman jumlah permintaan produk, harga produk, biaya pemesanan, biaya tenggang waktu sesuai dengan penerapan metode DRP dengan hasil lebih kecil bila dibandingkan dengan metode perusahaan.Total Cost (TC) sebesar Rp. 89.363.752,00. Sedangkan total biaya dengan perhitungan penerapan metode DRP adalah sebesar Rp. 71.502.667,00. Sehingga terjadi penurunan sebesar $20 \%$ [6].

Sistem distribusi merupakan salah satu persoalan yang muncul diperusahaan, suatu perusahaan akan dihadapkan pada masalah yang berkaitan dengan sistem distribusi produk. Masalah dapat terjadi apabila lokasi konsumen berada pada geografis yang terpisah-pisah, hal ini mengakibatkan perlunya persediaan pada beberapa lokasi pusat-pusat distribusi didaerah dan lokasi tertentu. Salah satu perusahaan air minum yang merupakan sebuah perusahaan yang bergerak pada bidang pemasaran minuman ringan tanpa alkohol menemukan persoalan terkait dengan distribusi produk. Pengiriman produk sudah dilakukan sesuai dengan permintaan pasar, diaman masing-masing konsumen dapat memperoleh produk dengan menggunakan sarana transportasi darat. Sistem distribusi yang dilakukan oleh perusahaan memiliki beberapa kelemahan, diantaranya adalah adanya keterlambatan pengiriman produk atas suatu pesanan, sering terjadinya kelebihan dan juga kekurangan akan permintaan produk pada suatu daerah dan juga sering terlambatnya produk sampai ke pusat distribusi. Dengan demikian, maka dilakukan penelitian dengan harapan dapat dilakukan pendistribusian produk secara tepat waktu, teratur, efektif, optimal dengan biaya yang dikeluarkan minimum. Perencanaan kebutuhan distribusi adalah suatu metode untuk menyelesaikan persoalan mengenai dampak yang ditimbulkan dari keterlambatan distribusi produk. Tujuannya adalah melakukan perencanaan, pengendalian, penjadwalan aktivitas distribusi sesuai dengan harapan perusahaan yaitu dengan optimal, tepat waktu guna meningkatkan kinerja distribusi perusahaan, sehingga keberhasilan dalam pemenuhan kebutuhan dan permintaan pelanggan dapat optimal. Hasil Penelitian menunjukkan bahwa adanaya penjadwalan yang tersusun dan perencanaan yang matang yang dapat digunakan untuk mendukung aktifitas distribusi agar lebih terstrukturdengan baik yang dapat mengurangi adanya kelebihan dan kekurangan produk [7][8].

Dalam penelitian lainnya mengenai penjadwalan aktivitas distribusi juga ditemukan masalah distribusi produk, dimana penelitian bertujuan untuk memperoleh keberhasilan perusahaan akan efektifitas distribusi yang telah dilakukan, perencanaan penjadwalan Distribution Requirement Planning (DRP) 2008-2013 guna menurunkan total biaya sesuai dengan aktivitas distribusi yang telah dilakukan. Selain itu, penelitian ini juga bertujuan untuk memprediksikan penjualan periode tahun 2014-2018. Data penelitian ini diperoleh dari perusahaan kemudian diobservasi dan dilakukan perhitungan , perencanaan dan penjadwalan distribusi yang sesuai. Hasil yang diperoleh menunjukkan adanya pengeluaran total biaya distribusi sebesar Rp. 7,536,728,631,621, yang menggunakan perhitungan secara konvensional sedangkan dengan menggunakan metode Distribution Requirement Planning (DRP) diperoleh total biaya periode sebesar $7,395,451,989,731.00$. Hal ini menunjukkan penurunan total biaya sebesar Rp. 141,276,641,890.00 atau 2\% dibandingkan metode perusahaan. Sehingga penggunaan metode DRP ini lebih efektif menurunkan total biaya terkait aktivitas distribusi. Dari perhitungan dengan menggunakan Distribution Requirement Planning (DRP) untuk peramalan permintaan produk dalam kurun waktu 2014-2018 berturutturut didapatkan 5,316,430 ton, 5,930,110 ton, $6,338,030$ ton, $6,745,940$ ton dan $7,153,860$ ton tahun 2018 dan proyeksi persediaan sebesar 0 atau tidak adanya persediaan [9][6].

Demikian halnya dengan PT. Bina Usaha Bersama Sehati merupakan perusahaan distributor walls ice cream, Distribusi yang dilakukan perusahaan didasarkan atas penjualan distributor sebagai gudang sebanyak rata-rata 9300 box (perbulan). pada pelaksanaannya perusahaan menerima 11.000 box dari medan (perbulan) sehingga selalu terjadi penumpukan produk disetiap distribution centre baik dikota Lhokseumawe maupun di kota Bireuen. Hal ini menunjukkan bahwa penjualan untuk semua jenis produk kurang terkontrol. Perusahaan belum memiliki suatu pengendalian, perencanaan serta penjadwalan produk sebagai suatu aktivitas distribusi sehingga setiap bulannya perusahaan menerima sejumlah yang dikirimkan oleh pusat distribusi dari kota Medan, padahal jumlah yang terjual perbulannya jauh dibawah jumlah yang dikirimkan, sehingga penumpukan produk selalu terjadi di setiap pusat distribusi Lhokseumawe dan Bireun. Hal ini yang mendorong untuk dilakukan penelitian pengenai penjadwalan distribusi produk pada perusahaan.

\section{METODE PENELITIAN}

Dalam penelitian ini menggunakan metode Distribution requirement planning (DRP), dimana perhitungan penentuan penjadwalan yang optimal dilakukan dengan merencanakan dan menjadwalkannya dengan menggunakan metode Distribution requirement planning (DRP), sesuai dengan 
tahapan yang telah ditentukan, yaitu pengumpulan dan perencanaan melaluii data peramalan produk, perhitungan safety stock dan persediaan bahan baku ekonomis (Eqonomic Order Quantity (EOQ).

\section{HASIL DAN PEMBAHASAN}

Dalam melakukan penelitian diperlukan data awal dengan hasil pengumpulan data yaitu data peramalan permintaan produk sesuai Tabel 1.

Tabel 1

Data peramalan permintaan produk ice Wall's periode Januari-Juni 2019

\begin{tabular}{lcc} 
& Wall's periode Januari-Juni 2019 \\
\hline Periode & $\begin{array}{c}\text { Lhokseumawe } \\
\text { (box/kardus) }\end{array}$ & $\begin{array}{c}\text { Bireuen } \\
\text { (box/kardus) }\end{array}$ \\
\hline Januari & 11497 & 17678 \\
Febuari & 12184 & 16475 \\
Maret & 17531 & 11356 \\
April & 9896 & 13218 \\
Mei & 14833 & 14881 \\
Juni & 13063 & 9951 \\
Total & 79005 & 83659 \\
\hline Sumber: Perusahaan & &
\end{tabular}

Data yang dibutuhkan dalam perhitungan persediaan untuk DC Lhokseumawe adalah sebagai berikut:

Perhitungan persediaan optimal, tingkat pelayanan dan biaya total dimulai dengan menghitung ukuran pemesanan optimal (q), safety stock (ss) dan reorder point (r) yaitu:

1. Hitung ukuran pemesanan ekonomis (q) :

$$
\begin{aligned}
q= & \sqrt{\frac{2 A D}{h}}=\sqrt{\frac{2 \times 452.500 \times 79005}{5100000}} \\
& =140195 \text { box }
\end{aligned}
$$

2. Hitung safety stock (ss)

$$
\begin{aligned}
\text { Ss } & =\text { s } \times \text { Z } \\
& =7960.40 \times 1.65 \\
& =11980 \text { box }
\end{aligned}
$$

3. Hitung reorder point $(\mathrm{r})$

$$
\begin{aligned}
\mathrm{r}= & \text { (jumlah penjualan harian } \mathrm{x} \text { lead time }) \\
& + \text { safety stock } \\
& =(599 \times 1)+11980 \\
& =12579 \text { unit }
\end{aligned}
$$

Hal ini berarti order quantity pada DC Lhokseumawe sekali pemesanan sebanyak 140195 box , safety stock sebanyak 11980 box dan reoder point yaitu 12579 unit. Rekapitulasi order quantity, reorder point dan safety stock untuk setiap DC dapat dilihat pada Tabel 2.

Tabel 2

Rekapitulasi Jumlah Order Quantity, Reorder Point dan Safety Stock setiap DC

\begin{tabular}{lccc}
\hline Distribusi Center & $\begin{array}{c}\text { Order } \\
\text { Quantity } \\
\text { (Box) }\end{array}$ & $\begin{array}{c}\text { Safety } \\
\text { Stock } \\
\text { (Box) }\end{array}$ & $\begin{array}{c}\text { Reorder Point } \\
\text { (Box) }\end{array}$ \\
\hline Lhokseumawe & 140195 & 11980 & 12579 \\
Bireuen & 155686 & 15600 & 16234 \\
\hline
\end{tabular}

Sumber: Pengolahan Data
Jumlah penjualan setiap minggu dari setiap distribusi center diperoleh dengan pembagian antara jumlah penjualan setiap distribusi center setiap bulan dengan jumlah minggu yang ada pada setiap bulan tersebut. Jumlah penjualan setiap distribusi center dapat dilihat pada Tabel 3.

Tabel 3

Penjualan Distribusi Center setiap Minggu

\begin{tabular}{lccc}
\hline Bulan & $\begin{array}{c}\text { Jumlah } \\
\text { Minggu }\end{array}$ & Lhokseumawe & Bireuen \\
& 2 & 5749 & 8839 \\
Januari & 2 & 6092 & 8238 \\
Febuari & 2 & 8766 & 5678 \\
Maret & 2 & 4948 & 6609 \\
April & 2 & 7471 & 7441 \\
Mei & 2 & 6532 & 4976 \\
Juni & 12 & 39502 & 41780 \\
Total & & &
\end{tabular}

Penentuan ukuran lot pemesanan dalam suatu sistem distribusi dipengaruhi oleh frekuensi pengiriman. Frekuensi pengiriman yang dilakukan oleh perusahaan dilakukan setiap bulan sesuai jumlah pesanan, sehingga data EOQ digunakan untuk menentukan ukuran lot adalah sebagai berikut:

1. Penjualan dalam 6 bulan (D) $=79005$ box

2. Standar deviasi penjualan (S) $=7260402$

3. Lead time (L) = 1 hari

4. Biaya pesan (A) $\quad=452.500 /$ kirim

5. Harga produk $(\mathrm{p}) \quad=30.000$ per box

6. Biaya simpan (h) $\quad=510.000 /$ box

7. Rata-rata Penjualan harian $=599$ box

8. Dengan perhitungan:

Teknik Ukuran Lot : Economic Order Quantity

Ongkos Pesan : Rp. 100.000,-

Ongkos Simpan : Rp. 13.000,-

Lead Time : : 1

\begin{tabular}{|c|c|c|c|c|c|c|c|}
\hline \multicolumn{8}{|c|}{ Projected On Hand : 11.000} \\
\hline \multirow{2}{*}{\multicolumn{2}{|c|}{$\begin{array}{l}\text { Lead Time } \\
\text { Lot size }\end{array}$}} & $: 1$ & & & & & \\
\hline & & \multicolumn{6}{|c|}{ Economic Order Quantity } \\
\hline \multirow{3}{*}{ Period } & \multirow{3}{*}{$\begin{array}{l}\text { Past } \\
\text { Due }\end{array}$} & \multirow{2}{*}{\multicolumn{6}{|c|}{$\begin{array}{l}2019 \\
\text { Bulan }\end{array}$}} \\
\hline & & & & & & & \\
\hline & & 1 & 2 & 3 & 4 & 5 & 6 \\
\hline \multicolumn{2}{|l|}{ GR } & 11.497 & 12.184 & 17.531 & 9.896 & 14.833 & 13.063 \\
\hline \multicolumn{2}{|l|}{$\mathrm{SR}$} & 84.615 & & & & & \\
\hline \multicolumn{2}{|l|}{$\mathrm{POH}$} & 73.118 & 66.934 & 43.403 & 33.507 & 18.674 & 5.611 \\
\hline \multicolumn{2}{|l|}{ PoRec } & 84.615 & & & & & \\
\hline \multicolumn{2}{|l|}{ PoRel } & & & & & & \\
\hline
\end{tabular}

Asumsi $\quad: 11.000$ unit/Bulan

Perhitungan EOQ adalah :

$E O Q=\sqrt{\frac{1 A \lambda}{h}}=\sqrt{\frac{1(100.000)(11.000)}{13.000}}=84.615$ wnit

Perhitungan DRP teknik Economic Order Quantity dapat dilihat pada Tabel 4.

Tabel 4

Distribution requirement planning pada DC Lhokseumawe 
Ongkos Pesan $=2 \times$ Rp. $100.000=$ Rp. 200.000

Ongkos Simpan $=241.247 \times$ Rp $13.000=$ Rp.3.136.211

Total Ongkos $=$ Rp.3.336.211.-

Dengan perhitungan yang sama untuk distribution centre kota Bireuen

Diketahui :

Teknik Ukuran Lot : Economic Order Quantity

Ongkos Pesan : Rp. 100.000,-

Ongkos Simpan : Rp. 13.000,-

Lead Time : : 1

Asumsi : 11.000 unit/Bulan

Hasil perhitungan EOQ adalah 84.615 unit

diperoleh EOQ untuk Hasil perhitungan EOQ adalah 84.615 unit pada pada DC Bireuen dengan perhitungan DRP teknik Economic Order Quantity sesuai Tabel 5.

Tabel 5

Distribution requirement planning pada DC Bireuen

\begin{tabular}{|c|c|c|c|c|c|c|c|}
\hline \multicolumn{8}{|c|}{ Projected On Hand : 11.000} \\
\hline \multirow{2}{*}{\multicolumn{2}{|c|}{$\begin{array}{l}\text { Lead Time } \\
\text { Lot size }\end{array}$}} & \multirow{2}{*}{\multicolumn{4}{|c|}{$\begin{array}{l}: 1 \\
: \text { Economic Order Ouantity }\end{array}$}} & & \\
\hline & & & & & & & \\
\hline \multirow[t]{2}{*}{ Period } & \multirow[t]{2}{*}{$\begin{array}{l}\text { Past } \\
\text { Due }\end{array}$} & \multicolumn{6}{|c|}{$\begin{array}{l}2019 \\
\text { Bulan }\end{array}$} \\
\hline & & 1 & 2 & 3 & 4 & 5 & 6 \\
\hline \multicolumn{2}{|l|}{ GR } & 17.678 & 16.475 & 11.356 & 13.218 & 14.881 & 9.951 \\
\hline \multicolumn{2}{|l|}{ SR } & 84.615 & & & & & \\
\hline \multicolumn{2}{|l|}{$\mathrm{POH}$} & 66.937 & 50.462 & 39.106 & 25.888 & 11.007 & 1.056 \\
\hline \multicolumn{2}{|l|}{ PoRec } & 84.615 & & & & & \\
\hline
\end{tabular}

Sumber :Pengolahan Data

Ongkos Pesan $=2 \times$ Rp. 100.000

$=$ Rp. 200.000

Ongkos Simpan $=194.456 \times \mathrm{Rp} 13.000=\mathrm{Rp} 2.527 .982$

Total Ongkos $=$ Rp.2.727.982.-

Total biaya distribusi dengan menggunakan metode DRP dapat dilihat pada Tabel 6 berikut.

Tabel 6

biaya pengadaan ice wall's dengan metode DRP

\begin{tabular}{ll}
\hline Distribution Center & Biaya Pengadaan \\
\hline Lhokseumawe & Rp. 3.336.211.- \\
Bireuen & Rp. 2.727.982.- \\
Grand Total & Rp. 6.064.193.- \\
\hline
\end{tabular}

Sumber :Pengolahan Data

Setelah melakukan perhitungan biaya produksi maka diperoleh hasil perhitungan biaya pengadaan selama 6 bulan yang dilakukan dengan metode perusahaan dan DRP, dan hasilnya menunjukkan bahwa total biaya dengan menggunakan metode perusahaan yakni sebesar 12.060.000,lebih kecil dari metode DRP yaitu Rp. 996.4139,- dengan selisih:

Rp. $12.060 .000-6.064 .193=$ Rp.5.995.807.

Rp. $\frac{12.060 .000-6.064 .193}{12.060 .000} \times 100 \%=4,9716=5 \%$
Biaya total dalam perhitungan dilakukan dengan perhitungan total biaya bagi kedua kota tersebut dengan menggunakan metode EOQ dengan hasil perhitungan biaya total Rp 6.064.193. Pada perhitungan biaya total perusahaan yaitu sebesar Rp 12.060.000. Dari hasil perhitungan kedua metode tersebut dipilihlah total biaya distribusi terkecil dengan selisih total biaya EOQ dengan metode perusahaan adalah sebesar Rp 5.995.807. Artinya bahwa bila perusahaan merencanakan penjadwalan DRP dengan menggunakan metode EOQ dalam pendistribusian produk ice wall's, maka pengoptimalan dan penghematan yang diperoleh sebesar Rp 5.995.807.

\section{KESIMPULAN}

Kesimpulan yang diperoleh adalah Perencanaan penjadwalan distribusi produk ice wall's dengan kapasitas penjualan guna meminimalkan biaya distribusi dengan metode DRP menghasilkan total costnya sebesar Rp. 6.064.193 dan terjadi penurunan sebesar $5 \%$ dari metode sebelumnya yang digunakan oleh perusahaan yaitu sebesar Rp. 12.060.000,-. Perencanaan penjadwalan distribusi disesuaikan berdasarkan hasil dari penjualan quantity, reorder point dan safety stcok dan setiap Distribution Centre yaitu distribution centre Lhokseumawe dan distribution centre Bireuen.

\section{UCAPAN TERIMA KASIH}

Ucapan terima kasih terutama ditujukan kepada Fakultas teknik Universitas Malikussaleh yang membantu dalam pembiayaan penelitian ini, dan juga kepada pihak yag terkait yaitu PT. Bina Usaha Bersama Sehati dan rekan kerja mahasiswa Shishilya Yazid yang telah membantu proses penyelesaian laporan kegiatan sehingga laporan penelitian selesai dkerjakan.

\section{DAFTAR PUSTAKA}

[1] D. Pramestari, "Penjadwalan Distribusi Produk Dengan Penerapan Metode Distribution Requirement Planning Di PT.X," IKRA-ITH Teknol. J. Sains Teknol., vol. 4, no. 1, pp. 42-50, 2020.

[2] R. Magdalena and T. Suli, "Forecasting Methods and Implementation of DRP (Distribution Requirement Planning) Methods in Determining the Master Production Schedule," IOP Conf. Ser. Mater. Sci. Eng., vol. 528, no. 1, 2019, doi: 10.1088/1757-899X/528/1/012049.

[3] M. R. Akmal, "Usulan perbaikan sistem penjadwalan distribusi menggunakan metode distribution requirement planning di PT . Coca cola amatil cabang pekanbaru," SiTekIn, vol. 11, no. 1, pp. 1-11, 2013, [Online]. Available: http://ejournal.uinsuska.ac.id/index.php/sitekin/article/view/567/539.

[4] D. Wahyuni, I. Budiman, and N. Matondang, "Minimisasi Biaya Distribusi produk Aluminium dengan Pendekatan Distribution Resource Planning Minimisasi," no. September, pp. 24-27, 2017, [Online]. Available: https://www.researchgate.net/publication/324246503_Minimisasi_Biay a_Distribusi_produk_Aluminium_dengan_Pendekatan_Distribution_R esource_Planning.

[5] S. Suradi, A. Haslindah, M. A. Buana Putra, and N. Ramadhani, "Optimasi Pendistribusian Produk dengan Menggunakan Metode Distribution Requirement Planning (DRP) (Studi Kasus di PT. Makassar Te'ne)," ILTEK J. Teknol., vol. 14, no. 01, pp. 1992-1997, 
2019, doi: 10.47398/iltek.v14i01.355.

[6] Meliana; Achmad Alfian, "Perencanaan Dan Penjadwalan Distribusi Produk Dengan Metode distribution Requirement Planning (DRP) Di Arnez De Lourdes Palembang," in Seminar Nasional IENACO -2015, 2015, no. 2009, pp. 260-267, [Online]. Available: https://publikasiilmiah.ums.ac.id/bitstream/handle/11617/5781/IENAC O 35 - Meliana, Achmad Alfian.pdf?sequence=1.

[7] A. R. Gifari and H. Suliantoro, "Penjadwalan Lifting Produk Premium88 dan Pertamax-92 Menggunakan Metode Distribution Requirement Planning ( DRP ) dalam Mengantisipasi Peramalan Demand per Periode Maret-April 2016," Ind. Eng. Online J., vol. 7, no. 2, pp. 1-5, 2018, [Online]. Available: https://ejournal3.undip.ac.id/index.php/ieoj/about/editorialPolicies\#ope nAccessPolicy.

[8] Irsan, "Analisis penjadwalan pada aktivitas distribusi teh hitam untuk meminimalkan Biaya produksi dengan metode distribution requirement planning (DRP) pada PT. Perkebunan nusantara vi unit produksi danau kembar, kabupaten solok," Teknologi, vol. 9, no. 1, pp. 55-64, 2019, [Online].

Available: http://lppm.upiyptk.ac.id/ojsupi/index.php/JTN/index Vol.

[9] Y. P. Kurniawan Kelen and O. R. Sikas, "Sistem Penjadwalan Distribusi Produk Sepeda Motor Menggunakan Metode Distribution Requirement Planning (DRP) Pada PT. Nusantara Surya Sakti (NSS) Cabang Kefamenanu," Saintekbu, vol. 11, no. 1, pp. 27-39, 2019, doi: 10.32764/saintekbu.v11i1.308. 